\title{
Surface physical chemistry properties in coated bacterial cellulose membranes with calcium phosphate
}

\author{
Gabriel Molina de Olyveira a,*, Pierre Basmaji ${ }^{\mathrm{b}}$, Ligia Maria Manzine Costa ${ }^{\mathrm{c}}$, Márcio Luiz dos Santos ${ }^{\mathrm{d}}$, \\ Carla dos Santos Riccardi ${ }^{\text {a,e }}$, Fernando Pozzi Semeghini Guastaldi ${ }^{f}$, Raquel Mantuaneli Scarel-Caminaga ${ }^{g}$, \\ Ticiana Sidorenko de Oliveira Capote ${ }^{\mathrm{g}}$, Elisabeth Pizoni ${ }^{\mathrm{a}}$, Antônio Carlos Guastaldi ${ }^{\mathrm{a}}$
}

\footnotetext{
a São Paulo State University (Unesp), Department of Physical Chemistry, Institute of Chemistry, Araraquara, SP 14800-900, Brazil

b Innovatec's-Biotechnology Research and Development, São Carlos, SP 13560-042, Brazil

c São Carlos School of Engineering, Materials Engineering Department, USP, São Carlos, SP 13566-590, Brazil

d Univ Fed ABC UFABC, CCNH, BR-09210190 Santo Andre, SP, Brazil

e Department of Bioprocess and Biotechnology, College of Agricultural Sciences, São Paulo State University, Botucatu 18603-970, SP, Brazil

${ }^{\mathrm{f}}$ Department of Diagnosis and Surgery, Araraquara Dental School, São Paulo State University, 14801-903, Brazil

g School of Dentistry, Morphology Department, UNESP, Araraquara, SP 14801-903, Brazil
}

\section{A R T I C L E I N F O}

\section{Article history:}

Received 13 July 2016

Received in revised form 6 December 2016

Accepted 2 March 2017

Available online 7 March 2017

\section{Keywords:}

Bacterial cellulose

Coated membrane

Regenerative medicine

Tissue regeneration

\begin{abstract}
A B S T R A C T
Bacterial cellulose has become established as a new biomaterial, and it can be used for medical applications. In addition, it has called attention due to the increasing interest in tissue engineering materials for wound care. In this work, the bacterial cellulose fermentation process was modified by the addition of chondroitin sulfate to the culture medium before the inoculation of the bacteria. The biomimetic process with heterogeneous calcium phosphate precipitation of biological interest was studied for the guided regeneration purposes on bacterial cellulose. FTIR results showed the incorporation of the chondroitin sulfate in the bacterial cellulose, SEM images confirmed the deposition of the calcium phosphate on the bacterial cellulose surface, XPS analysis showed a selective chemical group influences which change calcium phosphate deposition, besides, the calcium phosphate phase with different $\mathrm{Ca} / \mathrm{P}$ ratios on bacterial cellulose surface influences wettability. XTT results concluded that these materials did not affect significantly in the cell viability, being non-cytotoxic. Thus, it was produced one biomaterial with the surface charge changes for calcium phosphate deposition, besides different wettability which builds new membranes for Guided Tissue Regeneration.
\end{abstract}

(c) 2017 Elsevier B.V. All rights reserved.

\section{Introduction}

Tissue engineering is a recent field that creates functioning artificial tissues and organs. The major considerations in tissue engineering include both the type of cell and the substrate (scaffold) to be used. Many strategies use an artificial scaffold that functions as the ECM (extracellular matrix) to facilitate organization as well as differentiation of the implanted cells into a functional 3D tissue $[1,2]$.

Several techniques of surface modification of surgical implants were developed in order to optimize the adhesion of bone tissue and consequently the implant to the bone. We highlight, among them, the process of coating on implants that combine features of specific surface coating with the structural substrate properties. Increasing the biocompatibility and the bioactivity of titanium, the use of hydroxyapatite phase (HA) has been recommended due to its acceleration of the bone fixation, increasing the longevity of the surgical implant $[3,4]$.

\footnotetext{
* Corresponding author.

E-mail address: gabriel.ufabc@gmail.com (G.M. de Olyveira).
}

In this scope, the new membrane materials for the guided bone regeneration are expected in Dentistry Area. According to this concept, cells that have the capability to form bone, cementum and periodontal ligament must occupy the defect at the appropriate time and in the proper sequence to result in tissue regeneration as opposed to simple repair of the defect. Various membrane materials have been introduced over the years, and they have been showing that the biological and physical characteristics of the biomaterials used to manufacture membranes can significantly influence the barrier function as well as the host tissue response $[4,17]$.

The great interest in the search for new biopolymers with specificities to be used as scaffolds in tissue engineering has been increasing in recent years, which can be checked by numerous studies aiming the development of new biomaterials. It is known that bone tissue is the result of natural minerals, especially calcium phosphate nanocrystals and collagen, but there are many reports of problems involving the collagen uses, such as its high cost, difficulty in controlling infections and few definitions of commercial sources of this product. On the other hand, bacterial cellulose when compared to collagen eliminates the 
occurrence of infections and has higher mechanical properties such as strength and less biodegradability [5,19].

The benefits of cellulose, the most abundant biopolymer and polysaccharide were reported on applications for bone repair. Thus, the modification of cellulose appears to be a prerequisite in the mineralization process, which can be achieved through a chemical modification of the hydroxyl groups of cellulose chains with biomimetic calcium phosphate deposition, resulting in the bioactivity of this material $[6,18]$.

A research topic was based on new coated membranes using bacterial cellulose with chondroitin sulfate/hyaluronic acid for Guided Tissue Regeneration. Chondroitin sulfate and hyaluronic acid influence in bacterial cellulose were analyzed using transmission infrared spectroscopy (FTIR), XRD (X-ray diffraction) and scanning electron microscopy (SEM). FTIR analysis showed interaction between bacterial cellulose and calcium phosphate, XRD results obtained amorphous calcium phosphate and sodium chloride on bacterial cellulose. SEM images confirmed deposition of calcium phosphate on bacterial cellulose surface with different calcium phosphate particles morphology [7].

Chondroitin sulfate is a major component of extracellular matrix and it is important to maintaining the structural integrity of the tissue. This function is typically of proteoglycans, collectively termed the lecticans. As part of aggrecan, chondroitin sulfate is a major component of cartilage. The tightly packed and highly charged sulfate groups of chondroitin sulfate generate electrostatic repulsion that provides cartilage resistance of compression. Loss of chondroitin sulfate from the cartilage is a cause of osteoarthritis [8,9].

Based on these properties, therefore, a biomaterial should provide mechanical properties of the tissue to be regenerated and tissue/implant interface stability, as well as to be able to bone regeneration [10, 11]. Several works reported bacterial cellulose with chemical changes in bacterial surface for hydroxyapatite adhesion [16,17].

In this work, the bacterial cellulose fermentation process was modified by the chondroitin sulfate addition to the culture medium before the bacteria were inoculated. For guided bone regeneration purposes, biomimetic precipitation of calcium phosphate of biological interest on bacterial cellulose was studied. Then, it was produced one biomaterial with surface charge changes for calcium phosphate deposition, besides of, different wettability which builds new membranes for Guided Tissue Regeneration.

\section{Experimental section}

\subsection{Materials}

The bacterial cellulose (Nanoskin ${ }^{\circledR}$ ) raw material was provided by Innovatec's (São Carlos SP, Brazil). Chondroitin 4-sulfate was purchased from Sigma Aldrich.

\subsection{Methods}

\subsubsection{Synthesis of bacterial cellulose/chondroitin sulfate (BC/CS)}

The acetic fermentation process was achieved by using glucose as a carbohydrate source. The Results of this process are vinegar and a nanocellulose biomass. The modifying process is based on the addition of chondroitin sulfate $(1 \% \mathrm{w} / \mathrm{w})$ to the culture medium before the inoculation of the bacteria. Bacterial cellulose is produced by Gram-negative bacteria Gluconacetobacter xylinus, which can be obtained from the culture medium in the pure 3-D structure, consisting of an ultra-fine network of cellulose nanofibers $[5,6]$.

\subsubsection{Coated bacterial cellulose preparation}

In the present study, a novel biomaterial has been explored and different bacterial cellulose has been prepared; 1 ) bacterial cellulose/chondroitin sulfate $(\mathrm{BC} / \mathrm{CS})$. After, the modified bacterial cellulose membrane was immersed in the biomimetic coating method using the standard SBF solution and 3 new SBF solutions (SBF1, 2 and 3) with modified compositions, as described in Table 1 . Simulated body fluid (1.5SBF) was prepared using analytical grade reagents into demineralized water at $37{ }^{\circ} \mathrm{C}$ at $\mathrm{pH} 7.4$ for 7 days. The $1.5 \mathrm{SBF}$ solution was prepared from a protocol developed by Aparecida et al. [12]. After the immersion period, the substrates were removed from the solutions, washed with demineralized water, and coated Bacterial cellulose was dried at room temperature. The SBF solution composition was modified in order to allow different calcium phosphate coatings on the surface of the bacterial cellulose.

\subsection{Characterization}

\subsubsection{Transmission infrared spectroscopy (FTIR, Perkin Elmer Spectrum 1000)}

Influences of chondroitin sulfate in bacterial cellulose were analyzed in the range between 250 and $4000 \mathrm{~cm}^{-1}$ and with $2 \mathrm{~cm}^{-1}$ resolution with samples.

\subsubsection{Scanning electron microscopy (SEM)}

Images of uncoated and coated bacterial cellulose membrane were performed on a PHILIPS XL30 FEG. The samples were covered with gold and silver paint for electrical contact and to perform the necessary images.

\subsubsection{XPS (X-ray photoelectron spectroscopy)}

XPS analysis was carried out at a pressure of $<10^{-7}$ Pa using a commercial spectrometer (UNI-SPECS UHV System, Berlin, Germany). The $\mathrm{Mg} \mathrm{K}$ (line was used (he $(=1253.6 \mathrm{eV})$ and the analyzer pass energy was set to $10 \mathrm{eV}$. The inelastic background of the Ca 2p, P 2p, C 1s e $\mathrm{O}$ $1 \mathrm{~s}$ electron core-level spectra was subtracted using Shirley's method. The composition (at.\%) of the near surface region was determined with an accuracy of $\pm 10 \%$ from the ratio of the relative peak areas corrected by Scofield's sensitivity factors of the corresponding elements. The binding energy scale of the spectra was corrected using the $C 1 \mathrm{~s}$ hydrocarbon component of the fixed value of $285.0 \mathrm{eV}$. The spectra were fitted without placing constraints using multiple Voigt profiles. The width at half maximum (FWHM) varied between 1.2 and $2.1 \mathrm{eV}$ and the accuracy of the peak positions were $\pm 0.1 \mathrm{eV}$.

\subsubsection{Contact angle}

The measurements were performed using the sessile drop method on a Contact Angle System equipped with a camera. The sessile drop was dispensed by a syringe pump through a needle. Deionized water $(10 \mathrm{~mL})$ was dropped on bacterial cellulose membrane. Contact angles were measured $10 \mathrm{~s}$ after each drop of deionized water onto bacterial cellulose samples. The images were analyzed by Dropsnake software. All experiments were made at ambient temperature and for standardization it was performed three times each sample.

\subsection{Cells experiments-material extraction}

Eluates of the materials were made according to ISO 10993-12, considering the area $\left(6 \mathrm{~cm}^{2} / \mathrm{mL}\right)$. The materials were immersed in 1:1 Ham-

Table 1

Ionic concentration of simulated body fluid (SBF).

\begin{tabular}{|c|c|c|c|c|}
\hline \multirow[t]{2}{*}{ Ions } & \multicolumn{4}{|c|}{ Ionic concentration $\left(\mathrm{mmol} \cdot \mathrm{dm}^{-3}\right)$} \\
\hline & SBF0 & SBF1 & SBF2 & SBF3 \\
\hline $\mathrm{Na}^{+}$ & 142.0 & 140.4 & 140.4 & 140.4 \\
\hline $\mathrm{K}^{+}$ & 5.0 & - & - & - \\
\hline $\mathrm{Mg}^{2+}$ & 1.5 & - & 1,0 & - \\
\hline $\mathrm{Ca}^{2+}$ & 2.5 & 3.1 & 3.1 & 3.1 \\
\hline $\mathrm{Cl}^{-}$ & 147.8 & 142.9 & 142.9 & 142.9 \\
\hline $\mathrm{HPO}_{4}^{2-}$ & 1.0 & 1.86 & 1.86 & 1.86 \\
\hline $\mathrm{SO}_{4}^{2-}$ & 0.5 & - & - & - \\
\hline $\mathrm{HCO}_{3}^{-}$ & 4.2 & - & - & 5,0 \\
\hline
\end{tabular}


F10 + D-MEM medium (Sigma ${ }^{\circ}$, St. Louis, MO) without fetal bovine serum (FBS) at $37{ }^{\circ} \mathrm{C}$ for $72 \mathrm{~h}$, shaking at $133 \mathrm{rpm}$ in an incubator (New Brunswick Scientific - Excella E24 Incubator Shaker Series). Four different concentrations of all tested materials (bacterial cellulose, BC/CS, BC/CS (SBF0, SBF1, SBF2, SBF3) were used: 100\% (100\% eluate) and 50\% (50\% eluate + 50\% 1:1 Ham-F10 + D-MEM medium).

\subsection{CHO-K1 cell culture}

CHO-K1 cells were cultured in 1:1 Ham-F10 + D-MEM medium (Sigma ${ }^{\circledR}$, St. Louis, MO) supplemented with $10 \%$ FBS (Cultilab, Campinas, Brazil) and antibiotics [0.06 $\mathrm{g} \mathrm{L}^{-1}$ penicillin (Sigma®), $0.10 \mathrm{~g} \mathrm{~L}^{-1}$ streptomycin (Sigma $\left.{ }^{\circledR}\right), 1 \%$ kanamycin (Gibco, Carlsbad, CA) and $1 \%$ ciprofloxacin (Hifloxan ${ }^{\circledR}$, Halexistar)] in $25 \mathrm{~cm}^{2}$ culture flasks at $37^{\circ} \mathrm{C}$, $5 \% \mathrm{CO}_{2}$. Cells were used between the third and eighth passages.

\subsection{Cell viability - XTT assay}

After 24 h of seeding, CHO-K1 cells $\left(2 \times 10^{4}\right.$ cells seeded) were treated with $100 \%$ and $50 \%$ eluates of all tested materials for $24 \mathrm{~h}$ in 24-well plates. Each well containing eluate was supplemented with $10 \%$ FBS. Negative controls (NC) were wells with culture medium supplemented with $10 \%$ FBS in the absence of any eluate (untreated controls), while positive controls (PC), wells containing CHO-K1 cells were treated with doxorubicin $\left(3 \mathrm{~g} \mathrm{~mL}^{-1}\right)$ for $24 \mathrm{~h}$ (all treatments were carried out in duplicate). After the treatment, the cultures were washed with PBS and inserted into the culture medium supplemented with FBS. After $24 \mathrm{~h}$ of incubation, the cultures were washed with PBS solution and immediately $500 \mu \mathrm{L}$ of DMEM without phenol red were added, followed by the addition of $60 \mu \mathrm{L}$ of the XTT/ electron solution (50:1) (Cell Proliferation Kit II - Roche Applied Science). After $3 \mathrm{~h}$ reaction, the supernatant was transferred to a 96-well culture plate, and the absorbance was measured by a Microplate Reader (VersaMax, Molecular Devices, Sunnyvale, CA) at 492 and $690 \mathrm{~nm}$. The absorbance is directly proportional to the number of viable cells in each treatment after $24 \mathrm{~h}$ of exposure. Three independent experiments were conducted.

\subsection{Statistical analysis}

The results were expressed as mean and standard error. One-way analysis of variance (ANOVA) followed by Tukey's test was applied to the data. Data from treated groups were compared to the negative control using Dunnett's test.

\section{Results and discussion}

\subsection{FTIR-interaction between bacterial cellulose with chondroitin sulfate}

Influences of chondroitin 4-sulfate in bacterial cellulose were analyzed by ATR-FTIR in the range of $4000-2400 \mathrm{~cm}^{-1}$ with resolution of $2 \mathrm{~cm}^{-1}$. In the case of FT-IR spectra of bacterial cellulose/chondroitin sulfate $(\mathrm{BC} / \mathrm{CS})$, there were no shifts in the bands of carboxylate $1780 \mathrm{~cm}^{-1}$ and sulfate groups that appear at $1250 \mathrm{~cm}^{-1}$ and $1230 \mathrm{~cm}^{-1}$ in bacterial cellulose/chondroitin sulfate (Fig. 1) [6,7].

However, it has exhibited broad overlapping bands at $1564 \mathrm{~cm}^{-1}$ (aromatic $\mathrm{C}=\mathrm{C}$ stretching vibrations), as well as $\mathrm{N}-\mathrm{H}$ bending vibrations at $1508 \mathrm{~cm}^{-1}$ (Fig. 1) [5,6]. Besides, it was assigned an increase of intensity absorption bands at $1250 \mathrm{~cm}^{-1}$ and $1230 \mathrm{~cm}^{-1}$ due to sulfate-related modes, corresponding to antisymmetric and symmetric stretching of the sulfate group, respectively. The intensity of the antisymmetric bridge oxygen stretching band at $1163 \mathrm{~cm}^{-1}$ was reduced after the formation of $\mathrm{BC} / \mathrm{CS}$, indicating a change in the hydrogen-bonding of the oxygen bridge after the addition of chondroitin sulfate in the system. Besides, changes can be observed in the symmetrical stretching of $\mathrm{CH}_{2}$ bonds of bacterial cellulose structures at the absorption peak of

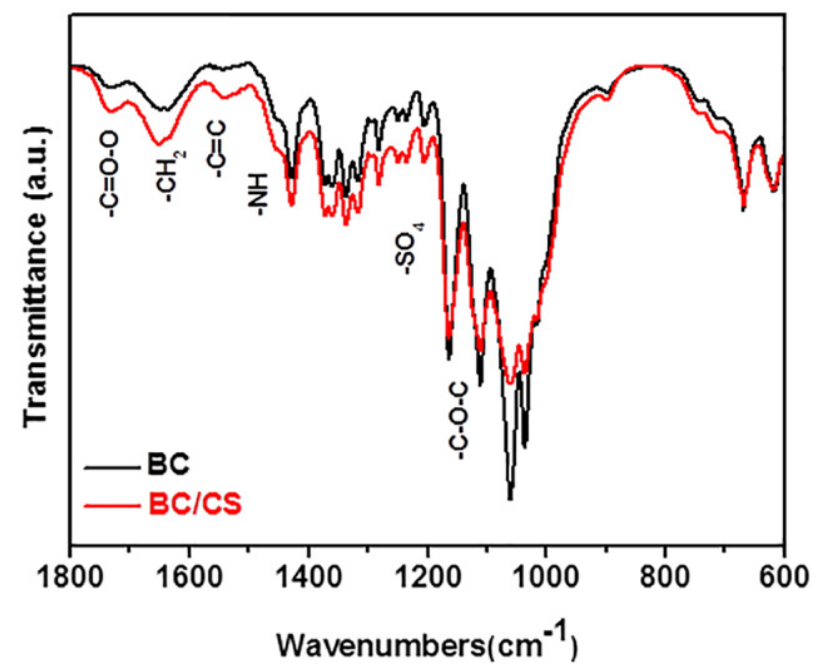

Fig. 1. FTIR spectra of bacterial cellulose and bacterial cellulose/chondroitin sulfate (BC/ CS).

$1640 \mathrm{~cm}^{-1}$. Another absorption peak was obtained in the range of $1490 \mathrm{~cm}^{-1}$ on both samples, which shows the presence of a carbonyl group in the bacterial cellulose together with bonds corresponding to those of glycoside, including $\mathrm{C}-\mathrm{O}-\mathrm{C}$ at $1162 \mathrm{~cm}^{-1}$ (as in the case of natural cellulose) (Fig. 1) [6,7]. Therefore, the results clearly show one possible interaction between bacterial cellulose and chondroitin sulfate, mainly by hydrogen interactions between hydroxyl and carbonyl groups.

\subsection{Morphological behavior}

Bacterial cellulose, bacterial cellulose/chondroitin sulfate (BC/CS) and coated bacterial cellulose membrane.

Bacterial cellulose membranes were characterized as obtained by fermentation and results showed bacterial cellulose surface as illustrated in Fig. 2a. Bacterial cellulose membranes were modified with chondroitin sulfate and the results showed bacterial cellulose surface as illustrated in Fig. 2b.

Then, it can be observed that bacterial cellulose was successfully modified by changing the fermentation medium and sample with chondroitin sulfate has little differences on surface morphology than the pure one. As observed in Fig. 2(c, d, e and f), a chondroitin sulfate/bacterial cellulose membranes were modified with calcium phosphate and produced samples with surface calcium phosphate morphology, respectively, SBF0, 1, 2 and 3.

As obtained from fermentation medium, bacterial cellulose has fibers width in nanometer sizes were tested as well as studied bacterial cellulose membrane with chondroitin sulfate (Fig. 2). Analyzing Table 1 and Fig. $2, \mathrm{Mg}^{2+}$ ions were detrimental in calcium phosphate formation on bacterial cellulose surface, such ions present in SBF0 and SBF2 showed low deposition of calcium phosphate on bacterial cellulose surface $[9,13]$.

\subsection{XPS}

The results of XPS analysis in bacterial cellulose/chondroitin sulfate (BC/CS) with calcium phosphate is illustrated in Fig. 3. Feature Binding Energy is identified with all present groups (, $\mathrm{O}$ and $\mathrm{N}$ from bacterial cellulose/chondroitin sulfate, an indicative of successful fermentative changes). Besides the $\mathrm{Na}, \mathrm{Cl}, \mathrm{Ca}$ and $\mathrm{P}$ corroborate with previous publications $[10,13]$, which show surface ( $\mathrm{NaCl}$ and calcium phosphate) in bacterial cellulose membrane $[10,13]$. 

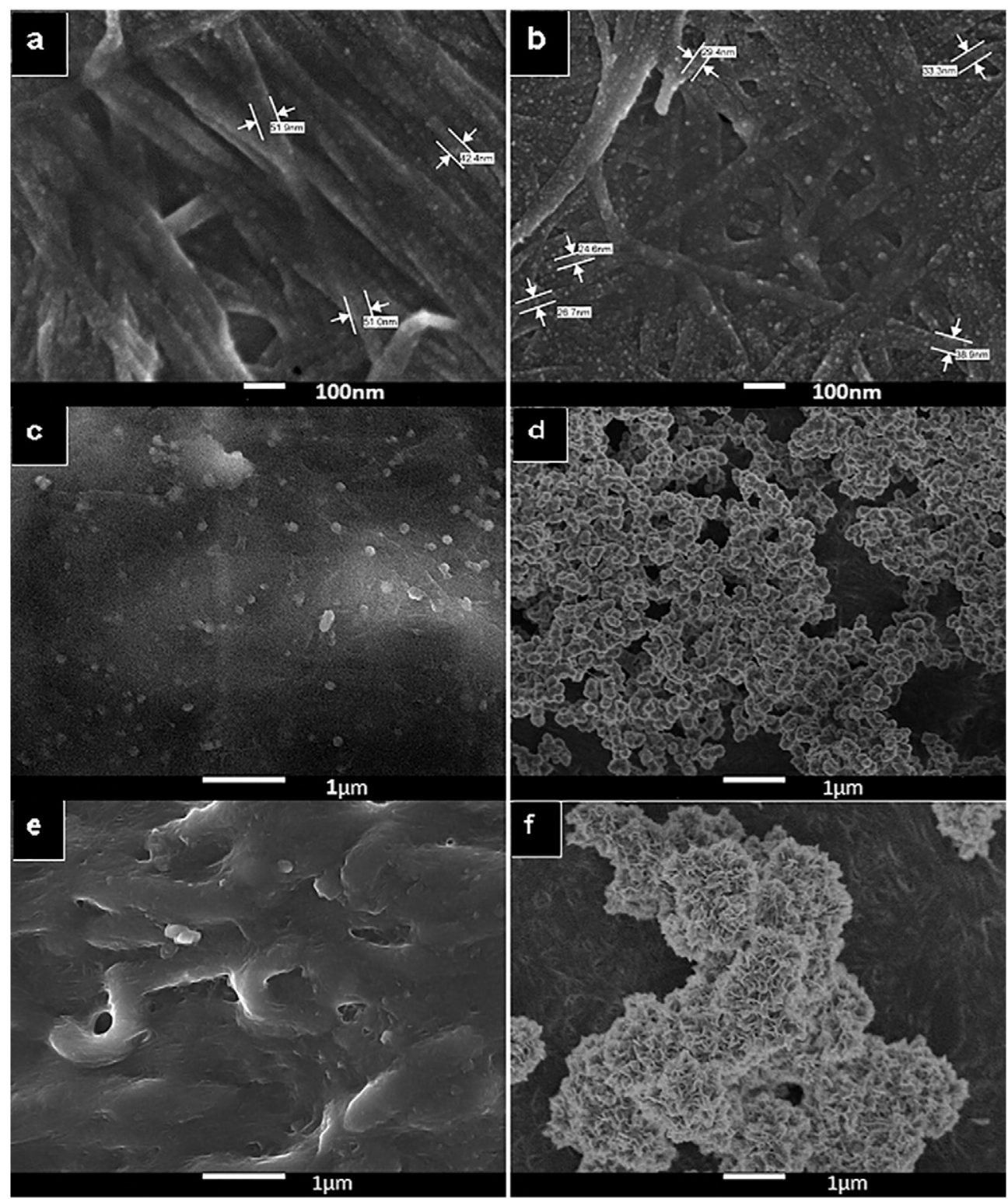

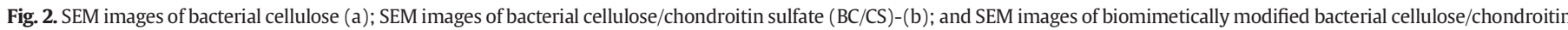
sulfate with calcium phosphate (c, d, e and f), respectively, SBF0, 1, 2 and 3.

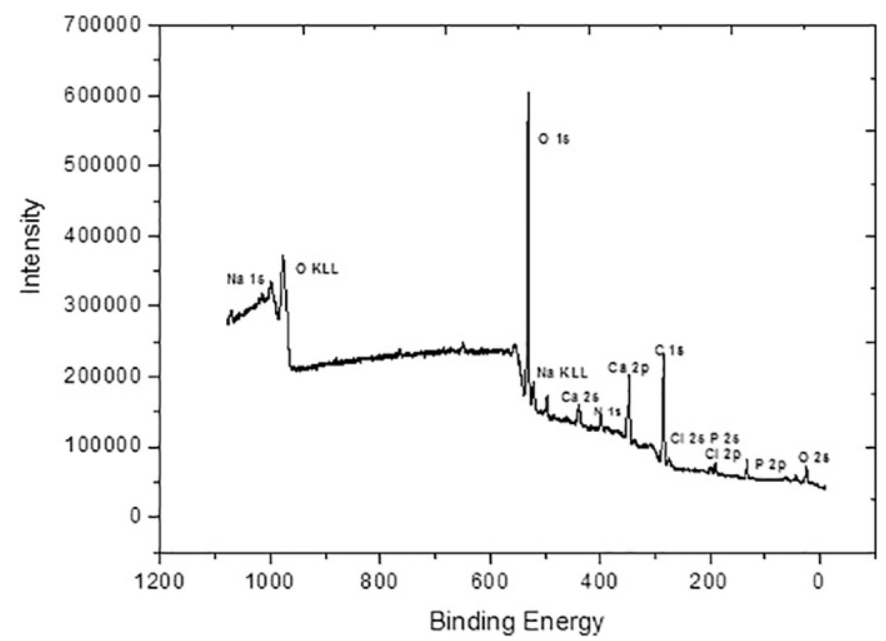

Fig. 3. Photoelectron spectrum shown over binding energy range of bacterial cellulose/ chondroitin sulfate $(\mathrm{BC} / \mathrm{CS})$.
In Fig. 4, it can be observed deconvolution of carbon and oxygen peaks, it could be seen changes in binding energy by calcium phosphate deposition. In Fig. 4, mainly in carbon deconvolution (Fig. 4(a-d)), there is hydrogen bond between chondroitin sulfate $\left(\mathrm{NH}_{2}\right.$ group) and bacterial cellulose ( $\mathrm{OH}$ group) in all tested membranes. Besides, in oxygen deconvolution (Fig. 4(e-h)), calcium phosphate has linkage preference with oxygen in all tested membranes.

Otherwise, in Fig. 4, there was a variable atomic percentage in $\mathrm{C}-\mathrm{H}$ bond mainly in carbon deconvolution (Fig. 4(a-d)), and a variable atomic percentage in $\mathrm{C}-\mathrm{O}$ bond in oxygen deconvolution (Fig. 4(e-h)). These changes are more evident mainly in BC/CS [(SBF1 and 3-Fig. 4b and f; $d$ and h, respectively)], which conclude higher interaction between coated bacterial cellulose with calcium phosphate in these tested SBFs. The area reduction is due to the busy links with chemical bonds.

It should be noted that related literature of calcium phosphate and XPS analysis [14,15], it has focus on the surface $\mathrm{Ca} / \mathrm{P}$ relation rather than on the group selective influences in its tested materials by XPS. Otherwise, there is a related discussion of XPS deconvolution peaks only with chemical treatment in bacterial cellulose [18]. 

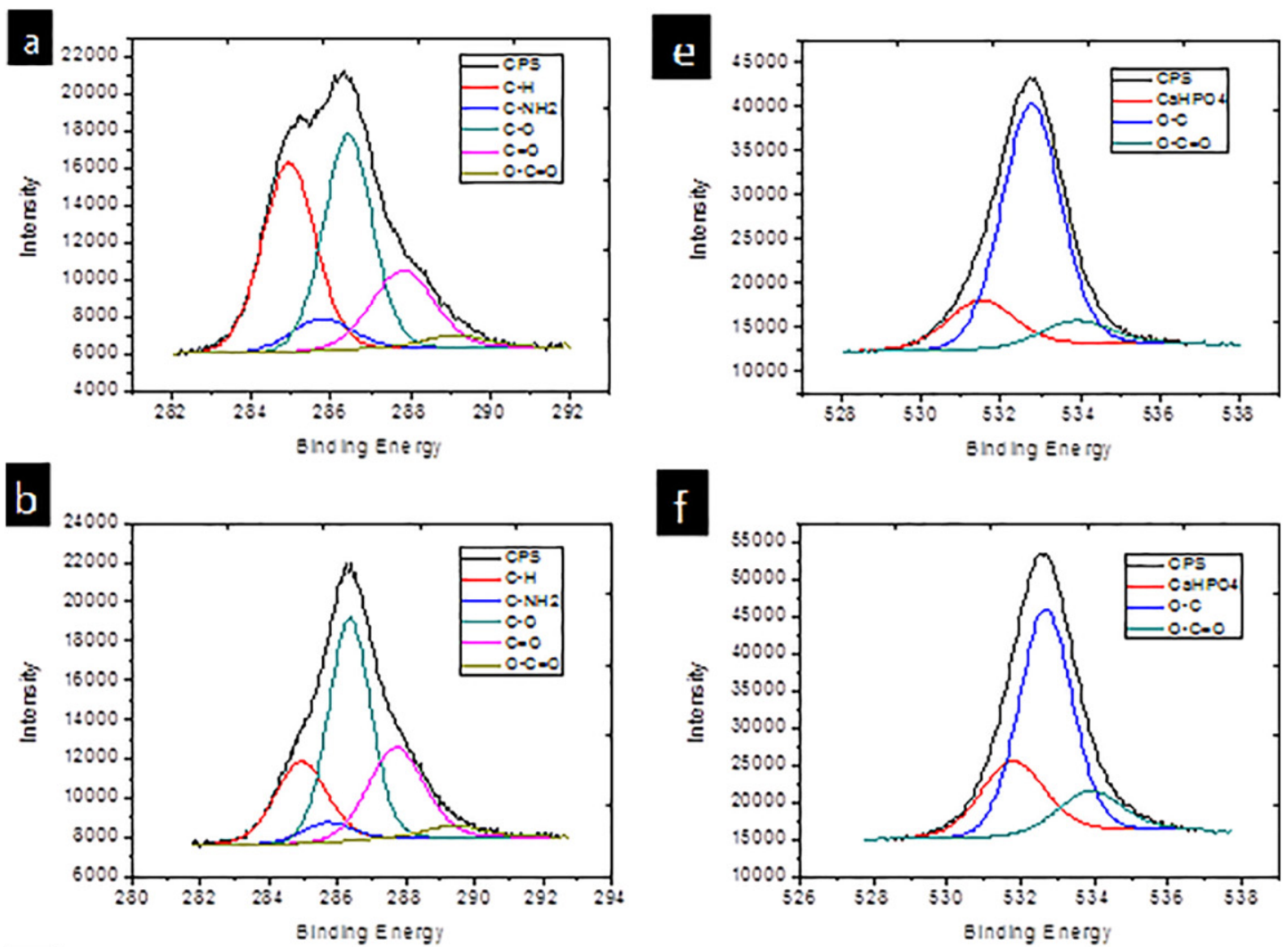

f

C
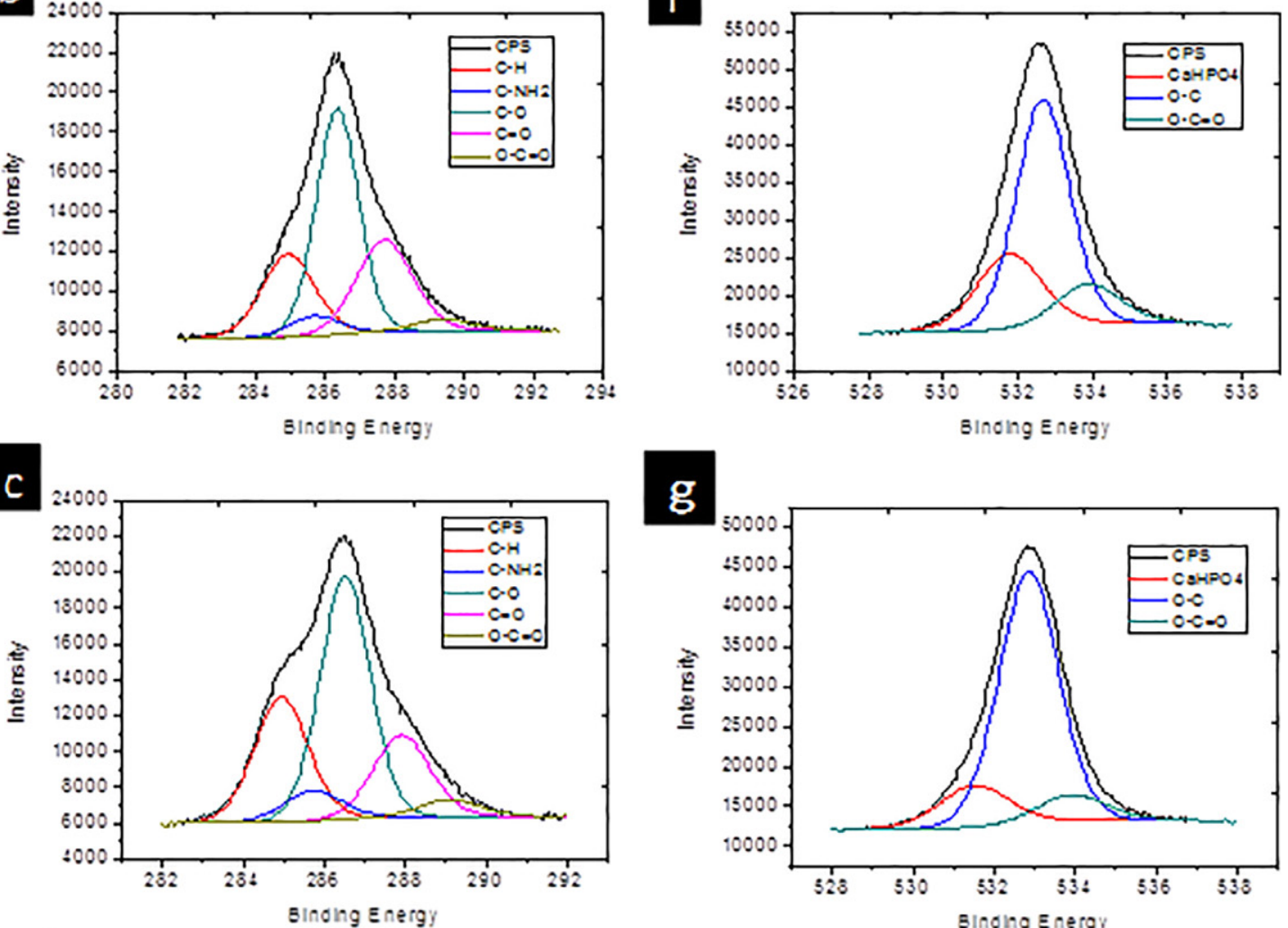

g

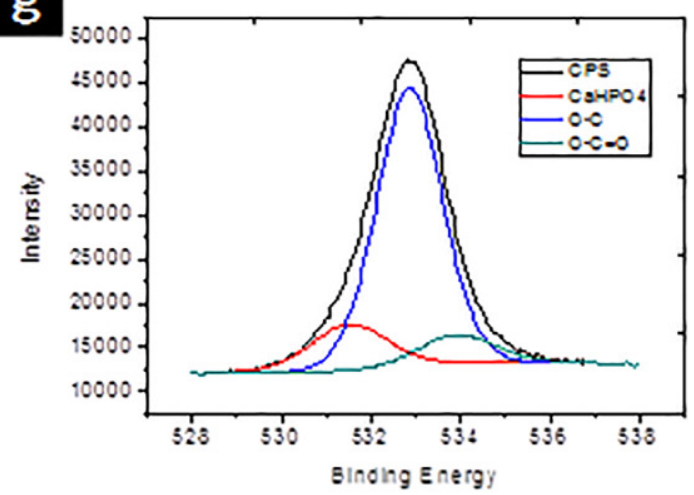

d
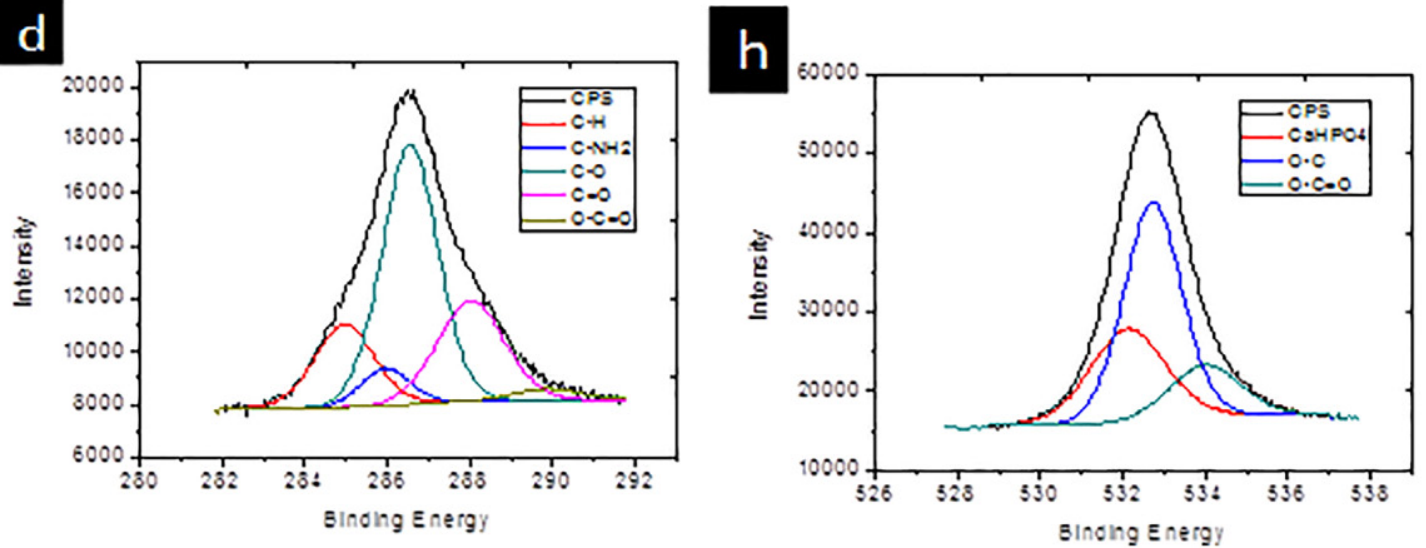

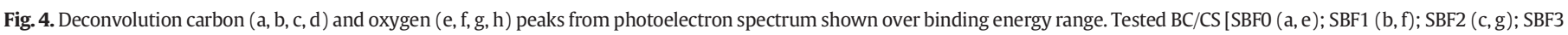
$(\mathrm{d}, \mathrm{h})]$. 


\subsection{Contact angle}

Wettability (W) is one required parameter for materials used in regenerative medicine because it can measure the surface physical chemistry properties due to the different surface energy of materials. Average wettability measurement has a variable contact angle range $(0 \leq W \leq 90$; $\mathrm{W}=0$ : total wettability; $\mathrm{W}=90$ : not wettability). Bacterial cellulose is a hydrophilic material with several surface hydroxyl groups. Then, it is expected changes in wettability with chondroitin sulfate molecules added in fermentation medium mainly because of lower surface hydroxyl groups.

Chondroitin sulfate and calcium phosphate changes in bacterial cellulose were analyzed by different contact angle measurements. It can be observed in Fig. 5(a-b) and Table 2 that chondroitin sulfate modification change surface physical chemistry properties due to a decreasing in the free groups such as hydroxyl and carboxylic groups in the sample as described by Xiong et al. [19].

However, in Table 2, it is a calcium phosphate surface with different $\mathrm{Ca} / \mathrm{P}$ ratios and solubility that change contact angle measurements. SBFO (Fig. 5c) sample because it has lower calcium phosphate deposition and more chloride sodium than the others, as observed by our previous works [6,7], it was more hydrophobic. Otherwise, SBF1 (Fig. 5d) was more hydrophilic because it has higher calcium phosphate deposition than SBF2 and 3, as analyzed in Fig. 2 and Table 2, besides it was observed by our previous works $[5,6]$.

\section{Table 2}

Average contact angle of bacterial cellulose (a); bacterial cellulose/chondroitin sulfate (BC/CS)-(b); coated BC/CS with SBF0 (c); SBF1 (d); SBF2 (e); and SBF3 (f).

\begin{tabular}{ll}
\hline Bacterial cellulose & Contact angle $(\theta)$ \\
\hline Bacterial cellulose (a) & 19,37 \\
BC/CS (b) & 31,1 \\
BC/CS (SBF0) - (c) & 75,22 \\
BC/CS (SBF1) - (d) & Near zero \\
BC/CS (SBF2) - (e) & 32,33 \\
BC/CS (SBF3) - (f) & 23,23 \\
\hline
\end{tabular}

In conclusion, different surface physical chemistry properties showed by XPS are crucial for understanding the preferential groups interaction in chemical bond that change calcium phosphate deposition, besides, wettability has influences of calcium phosphates with different $\mathrm{Ca} / \mathrm{P}$ ratios on bacterial cellulose surface.

\subsection{XTT analysis}

Evaluation of Bacterial cellulose, BC/CS and coated BC/CS (SBF0, SBF1, SBF2, SBF3) cytotoxicity was performed by cell viability test using Chinese hamster ovary cells ( $\mathrm{CHO}-\mathrm{K} 1)$ because their structures and functions are common to most types of cells, i.e., the objective was to determine the basal cytotoxicity potential of the materials [20].

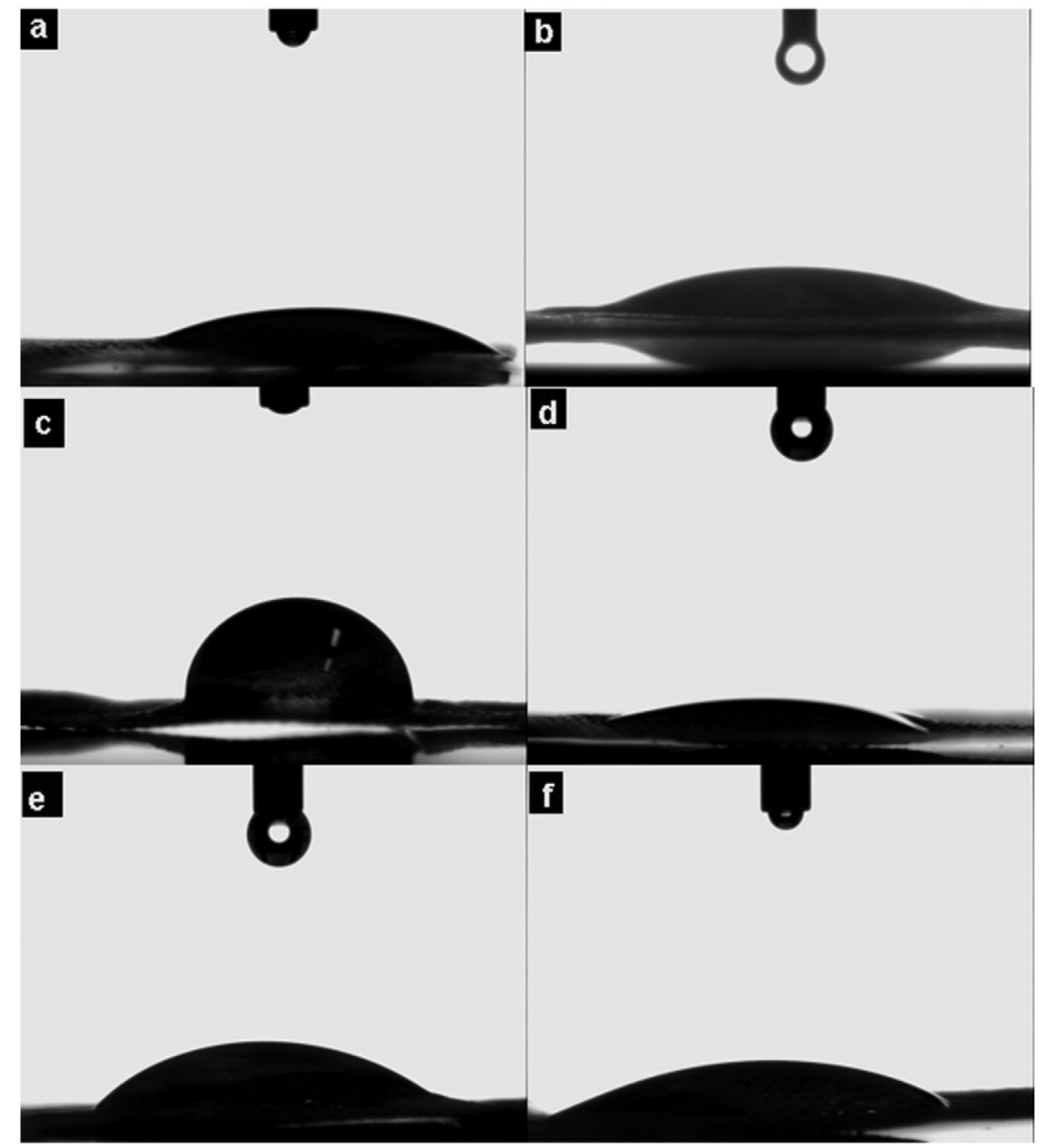

Fig. 5. Bacterial cellulose (a); bacterial cellulose/chondroitin sulfate (BC/CS)-(b); coated BC/CS with SBF0 (c); SBF1 (d); SBF2 (e); and SBF3 (f). 
The respective materials were investigated with the following dimensions: $5 \mathrm{~mm}$ in diameter and standard thickness, according to ISO 10993-3 (2003), besides the tested medical device was in "ready-touse" state. In addition, it was followed the ISO 10993-5 (2009), which materials with several shapes, sizes or physical states, may be tested without modification in the cytotoxicity tests. The cell viability is related to the absorbance measure. Negative control was considered $100 \%$ cell viability.

Recent literature reports cytotoxic evaluation of hydroxyapatite with negative cytotoxicity results in both researches, respectively, using hydroxyapatite extracts [21] and with eluates range [20].

Fig. 6 shows the cell viability (\%) expressed as mean and standard error. Cell viability of all eluate concentrations of bacterial cellulose, $\mathrm{BC} / \mathrm{CS}$ and $\mathrm{BC} / \mathrm{CS}$ (SBF0, SBF1, SBF2 and SBF3) were not significantly different from NC ( $p>0.05$; Dunnett). It is interesting the range of the concentration because the material can be cytotoxic at some concentration and in other it cannot, besides, it is important to create a similar body fluid on the biomaterial contact. Therefore, these materials did not significantly affect the cell viability, being non-cytotoxic, corroborating with recent literature results $[21,22]$.

\section{Conclusion}

Bacterial cellulose was successfully modified by changing the fermentation medium as shown with SEM and FTIR, which produced materials with different calcium phosphate deposition and surface morphology. Bacterial cellulose and bacterial cellulose/chondroitin sulfate have good calcium phosphate deposition over time among tested samples, being an extremely effective material for tissue regeneration applications. XPS presents all groups which are created on the surface bacterial cellulose such as $\mathrm{Na}, \mathrm{Cl}, \mathrm{Ca}$ and $\mathrm{P}$ corroborating with previous publications of our group. Preferably, mainly in Carbon deconvolution, there is a hydrogen bond between chondroitin sulfate $\left(\mathrm{NH}_{2}\right.$ group) and bacterial cellulose ( $\mathrm{OH}$ group) in all tested membranes. Besides, in oxygen deconvolution, calcium phosphate has linkage preference with oxygen in all tested membranes. Contact angle measurement shows that chondroitin sulfate and surface calcium phosphate, change properties hydrophobic and hydrophilic, respectively. In conclusion, different surface physical chemistry properties showed by XPS are crucial for understanding preferential chemical groups interaction that change calcium phosphate deposition, besides, wettability has influences of calcium phosphates with different $\mathrm{Ca} / \mathrm{P}$ ratios on bacterial cellulose surface. XTT results showed that these materials did not significantly affect cell viability, being non-cytotoxic.

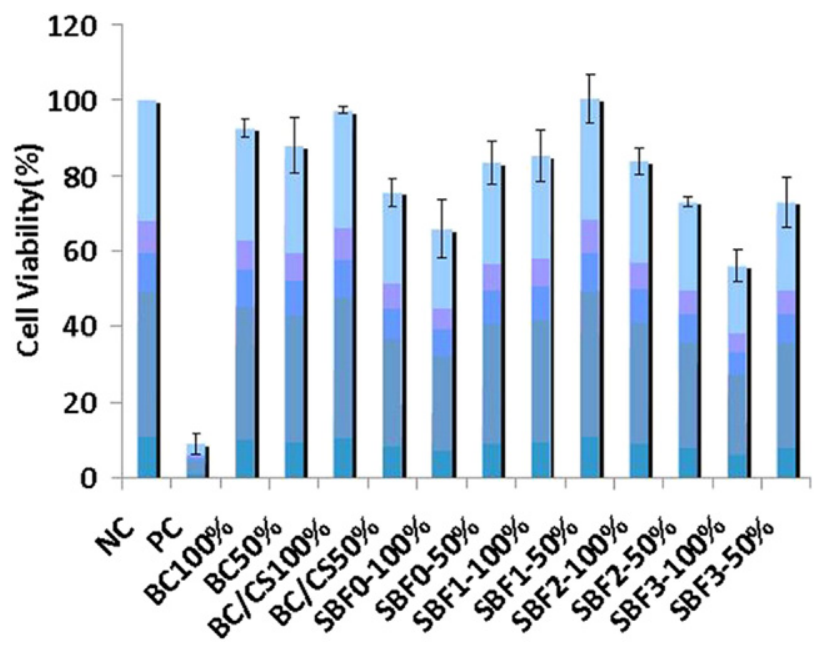

Fig. 6. Cell viability obtained from XTT test for negative control (NC), positive control (PC), bacterial cellulose, $\mathrm{BC} / \mathrm{CS}$ and coated $\mathrm{BC} / \mathrm{CS}$ with SBFs.

\section{Acknowledgement}

The authors thank Nanoskin ${ }^{\circledR}$ (Brazil), CNPq (National Council for Scientific and Technological Development)-Brazil, FAPESP (State of São Paulo Research Foundation)-Brazil for financial support and Elisabeth Pizoni (English language reviewer).

\section{References}

[1] G. Helenius, H. Bäckdahl, A. Bodin, U. Nannmark, P. Gatenholm, B. Risberg, In vivo biocompatibility of bacterial cellulose, J. Biomed. Mater. Res. 76A (2006) 431-438.

[2] L. Hong, Y.L. Wang, S.R. Jia, Y. Huang, C. Gao, Y.Z. Wan, Hydroxyapatite/bacterial cellulose composites synthesized via a biomimetic route, Mater. Lett. 60 (2006) $1710-1713$.

[3] Y.Z. Wan, L. Hong, S.R. Jia, Y. Huang, Y. Zhu, Y.L. Wang, H.J. Jiang, Synthesis and characterization of hydroxyapatite-bacterial cellulose nanocomposites, Compos. Sci. Technol. 66 (2006) 1825-1832.

[4] Y.Z. Wan, Y. Huang, C.D. Yuan, S. Raman, Y. Zhu, H.J. Jiang, F. He, C. Gao, Biomimetic synthesis of hydroxyapatite/bacterial cellulose nanocomposites for biomedical applications, Mater. Sci. Eng. C 27 (2007) 855-864.

[5] G.M. Olyveira, M.L. Santos, P.B. Daltro, P. Basmaiji, G.C. Daltro, A.C. Guastaldi, Bacterial cellulose/chondroitin sulfate for dental materials scaffold, J. Biomater. Tissue Eng. 4 (2014) 150-154

[6] G.M. Olyveira, M.L. Santos, L.M.M. Costa, P.B. Daltro, P. Basmaji, G.C. Daltro, A.C. Guastaldi, Bacterial cellulose biocomposites for guided tissue regeneration, Sci. Adv. Mater. 6 (2014) 2673-2678.

[7] G.M. Olyveira, M.L. Santos, L.M.M. Costa, P.B. Daltro, P. Basmaji, G.C. Daltro, A.C. Guastaldi, Bacterial cellulose nanobiocomposites for dental materials scaffolds, J. Biomater. Tissue Eng. 4 (2014) 536-542.

[8] G.M. Olyveira, G.A.X. Acasigua, L.M.M. Costa, C.R. Scher, L.X. Filho, P.H.L. Pranke, P. Basmaji, Human dental pulp stem cell behavior using natural nanotholits/bacterial cellulose scaffolds for regenerative medicine, J. Biomed. Nanotechnol. 9 (2013) 1370-1377.

[9] G.M. Olyveira, L.M.M. Costa, C.S. Riccardi, M.L. Santos, P.B. Daltro, P. Basmaji, G.C. Daltro, A.C. Guastaldi, Bacterial cellulose for advanced medical materials, in: A.M. Grumezescu (Ed.), Nanobiomaterials in Soft Tissue Engineering, Elsevier, Romania 2016, pp. 57-82

[10] G.M. Olyveira, C.S. Riccardi, M.L. Santos, L.M.M. Costa, P.B. Daltro, P. Basmaji, G.C. Daltro, A.C. Guastaldi, Physically modified bacterial cellulose biocomposites for dental materials scaffolds, Mater. Focus 4 (2015) 111-117.

[11] C.J. Grande, F.G. Torres, M.C.M. Gomez, M.C. Baño, Nanocomposites of bacterial cellulose/hydroxyapatite for biomedical applications, Acta Biomater. 5 (2009) 1605-1615.

[12] A.H. Aparecida, M.V.L. Fook, A.C. Guastaldi, Biomimetic apatite formation on ultrahigh molecular weight polyethylene (UHMWPE) using modified biomimetic solution, J. Mater. Sci. Mater. Med. 20 (2009) 1215-1222.

[13] G.M. Olyveira, M.L. Santos, C.S. Riccardi, L.M.M. Costa, P.B. Daltro, P. Basmaji, G.C. Daltro, A.C. Guastaldi, Physically modified bacterial cellulose biocomposites for guided tissue regeneration, Sci. Adv. Mater. 7 (2015) 1657-1664.

[14] T. Tsushida, J. Kubo, T. Yoshioka, S. Sakuma, T. Takegushi, W. Ueda, Reaction of ethanol over hydroxyapatite affected by Ca/P ratio of catalyst, J. Catal. 259 (2008) 183-189.

[15] K. Kieswetter, T.W. Bauer, S.A. Brown, F. Van Lente, K. Merritt, Characterization of calcium phosphate powders by ESCA and EDXA, Biomaterials 15 (1994) 183-188.

[16] M. Yoshinari, Y. Ohtsuka, T. Dérand, Thin hydroxyapatite coating produced by the ion beam dynamic mixing method, Biomaterials 15 (1994) 529-535.

[17] K.A. Zimmermann, J.M. Leblanc, K.T. Sheets, R.W. Fox, P. Gatenholm, Biomimetic design of a bacterial cellulose/hydroxyapatite nanocomposite for bone healing applications, Mater. Sci. Eng. C 31 (2011) 43-49.

[18] J. Li, Y. Wan, L. Li, H. Liang, J. Wang, Preparation and characterization of 2,3dialdehyde bacterial cellulose for potential biodegradable tissue engineering scaffolds, Mater. Sci. Eng. C 29 (2009) 1635-1642.

[19] G. Xiong, H. Luo, C. Zhang, Y. Zhu, Y. Wan, Enhanced biological behavior of bacterial cellulose scaffold by creation of macropores and surface immobilization of collagen, Macromol. Res. 23 (2015) 734-740.

[20] S. Jantová, S. Letasiová, M. Theiszová, M. Palou, Comparison of murine fibroblast cell response to fluor-hydroxyapatite composite, fluorapatite and hydroxyapatite by eluate assay, Acta Biol. Hung. 60 (2009) 89-107.

[21] N.F. Rajab, T.A. Yaakob, B.Y. Ong, M. Hamid, A.M. Ali, B.O. Annuar, S.H. InayatHussain, DNA damage evaluation of hydroxyapatite on fibroblast cell L929 using the single cell gel electrophoresis assay, Med. J. Malays. 59 (2004) 170-171.

[22] M. Theiszová, S. Jantová, S. Letasiová, L. Valík, M.T. Palou, Comparative study of a new composite biomaterial fluorhydroxyapatite on fibroblast cell line NIH-3T3 by direct test, Biologia 63 (2008) 273-281. 